\title{
NEETs and "Structured Social Interventions" in Rural Areas: The Case of Thessaly in Greece
}

\author{
Christos Goulas $^{1,2}$, Nikos Fotopoulos ${ }^{3,4}$, Kostas Boukouvalas $^{2} \&$ Polina Fatourou $^{4}$ \\ ${ }^{1}$ Neapolis University Pafos, Pafos, Cyprus \\ ${ }^{2}$ Institute of Labor of the Greek General Confederation of Labor, Athens, Greece \\ ${ }^{3}$ Department of Social and Education Policy, University of Peloponnese, Corinth, Greece \\ ${ }^{4}$ Center for Educational Policy Development of the Greek General Confederation of Labor, Athens, Greece \\ Correspondence: Polina Fatourou, Center for Educational Policy Development of the Greek General Confederation of \\ Labor, Athens, 10434, Greece.
}

Received: October 16, 2021

doi:10.11114/jets.v10i1.5376
Accepted: November 12, $2021 \quad$ Online Published: November 13, 2021

URL: https://doi.org/10.11114/jets.v10i1.5376

\begin{abstract}
This article aims at approaching the phenomenon of Young people Not in Education, Employment or Training (NEETs) using the empirical data from an action against unemployment in the region of Thessaly in Greece. The main purpose of the study was to examine the attitudes and perceptions of NEETs on important issues related to employment, training, entrepreneurship, as well as their main decisions and perspectives regarding their future. This approach tries to shape a multidimensional proposal which is linked to the core peculiarities of the region of Thessaly by highlighting the transition from "specialized individual action plans" to "structured social interventions". In conclusion, it attempts to promote a structured and applicable policy framework, shedding light on the dimensions of a crucial social issue such as NEETs promoting the drastic role of structured interventions on local and regional level.
\end{abstract}

Keywords: NEETs, rural areas, youth unemployment, training

\section{Introduction}

The phenomenon of Young people Not in Education, Employment, or Training (NEETs) that has appeared not only in Greece but throughout Europe (Eurofound 2012, 2014, 2016), confirms the structural crisis that Western societies are going through for many years now (Kyridis, \& Fotopoulos, 2016). Additionally, it reflects the wide level of social, economic, educational, and cultural inequalities, thus underlying the urgent need for a well-structured intervention, especially for those who are socially vulnerable and drastically affected by the consequences of educational and social exclusion. In recent years in Greece (Papadakis, Kyridis \& Papargyris 2015), a tough program of economic austerity with many "violent" fiscal adjustments was imposed resulting into more negative consequences, especially for those who were under the pressure of extremely negative circumstances. This period of fiscal consolidation has undoubtedly led to a dramatic decline of living standards for thousands of people proving a significant impact on society. For example, it drove hundreds of thousands of overqualified young people abroad while degrading the value and symbolic status of diplomas of other young people who continued to struggle with the pathogeny of unemployment, professional and social exclusion, respectively.

Within these extremely difficult conditions, the disorganization of social space was intensified by new forms of pathogenies whose main characteristics were unemployment, low wages, flexible working conditions, precarious labour relations, job insecurity, a feeling of uncertainty etc. (Fotopoulos, 2013). Additionally, other social groups were directly faced with new conditions of material deprivation due to losing their jobs or inability to find others. Some were deprived of benefits of social protection, resulting in the absence of a social solidarity network to be more obvious than ever (Papadakis, Kyridis \& Fotopoulos, 2016).

Our approach aims at analyzing the phenomenon of Young people Not in Education, Employment or Training (NEETs) using the empirical data from a structured venture against unemployment in the region of Thessaly in modern Greece. Specifically, our empirical findings, principally emerged from a field research on a NEETs group in the region of Thessaly in the context of a project against unemployment, while our research project was based on a quantitative 
analysis, which we approached interpretatively through the tools of a sociological method of analysis. It is worth mentioning that the program initially concerned 1,100 people, of which 557 were fired from the Supermarket Larissa SA and 543 were young people, both unemployed and not in education or training, aged 15-29 years. The total number of beneficiaries finally participating in the E.G.F actions was 497 people who had been fired by the Super Market Larisa out of whom 482 were NEETs.

Through this project, we had the opportunity for a deeper analysis on personal attitudes and perceptions of NEETs in Thessaly, seeking a broader interpretation that contributes to a drastic tackle of educational, occupational and social exclusion. Through data quantitative statistical approach, we have been led to the main conclusions for the attitudes and perceptions of NEETs on important issues such as employment, training, entrepreneurship, relocation to another area, the relationship between personal and professional life, the role of others in their lives, in their decisions and perspectives and so on.

Apart from the elaboration of the empirical data, our article covers a widely theoretical and conceptual sociological framework. It uses dimensions from the theory of "cultural capital" and the core concepts of the "cultural reproduction" theory in order to interpret the correlation between different educational attainment levels and career paths and the cultural and socio-economic background. With no doubt approaches as Pierre Bourdieu's (Huang, 2019) or Basil Bernstein's (Jenks, 1993) respectively have been used in our analysis for understanding the cultural identity and social background of NEETs. At the same time, through these approaches we try to see the drastic intervention of inequalities both on educational choices and professional paths. This study attempts to offer a structured and applicable policy framework using the research facts which link the coordinates of a broader social issue with the necessary interventions on the level of local and regional conditions and particularities.

\section{Theoretical and Conceptual Framework: Dimensions and Parameters}

The term NEETs (Not in Employment, Education or Training) is a relatively new indicator which is used both in social and educational dialogue as well as in the media sphere. Undoubtedly, the reasons are many. Social scientists and experts are studying the phenomenon with concern because a significant part of the younger generation is threatened by many dimensions of exclusion (educational, economic, social). At the same time, it seems to be directly vulnerable to social marginalization proving a peculiar tendency towards a new kind of social pathogeny. Governmental authorities seem to seriously theorize the phenomenon of NEETs, not only because they understand the concerns of academia and civil society actors, but also because young people who are not involved in education, work or training cost a lot in the "social state" through social security measures and as well as other subsidiary funding tools (Maguire, 2015).The findings of a research by Impetus PEF, operating in the United Kingdom are also extremely impressive. Each year, additional social benefits and resources spent on tackling health care services or juvenile delinquency, are estimated at around 77 billion pounds a year.

However, the term "NEETs" appeared in the public sphere around the 1990s, developing a dynamic orbit through the period of global financial crisis in the last decade. The term used to cover social groups with different characteristics who had more possibilities to become vulnerable (Mascherini, 2019). Additionally, it was shaped to express the heterogeneity of the populations who possibly were at risk of becoming NEETs showing that it is a very inclusive and complicated phenomenon that should be placed at the top of the political agenda of our times. Hence, it is very important to mention that a very strong critique has been developed around the usage of the term by many authors and experts (Yates, S., \& Payne, M. (2006). For instance, a characteristic case is the one of Sara Elder who developed her thesis in an I.L.O. study entitled "What does NEETs mean and why is the concept so easily misinterpreted?" (Elder, S. (2015). The researcher claims that none of the modern terms and definitions could completely cover the phenomenon, mainly because most of them are imperfect, insufficient or incorrect. She states that often in research there is difficulty in finding data on work and its various forms (formal employment, undeclared work, precarious work) or on issues related to unemployment, discouragement, marginalization, and social exclusion. She described the term "lost generation" often used for NEETs as an "excessive" one, citing an example that for $37 \%$ of emerging economies the average percentage of "discouraged young people" in the labor market was "a maximum of 3.7\%". She also considers that the term unemployment is included in the term NEETs- the equation of the unemployed with the inactive youth is wrong, as in most surveys most of the unemployed youth are women who stay at home and take care of their families following a standard of social life which is compatible with traditional values. Given that most inactive young people are young women excluded from education, work and training for various reasons, perhaps the most inclusive interpretation of the term NEETs is that they are: "young people aged 15-34 years old, unemployed, or inactive, and who are not attending any education or training courses according to the International Labour Organization (ILO) definition and the European Commission Employment Committee (EMCO)". Specifically, "the latest data available from Eurostat for 2019 shows that NEET rates in the EU were 5.6\% for youths aged 15-19, $14.5 \%$ for people aged 2024, $17.2 \%$ for those aged 25-29, and 17.4\% for those aged 30-34" (Simões, 2021). 
According to the special features of our article, it is important to highlight the dimension of NEETs in rural areas. This is because according to most data, the percentages of NEETs appear to be increased in rural areas, a fact that is obviously related to the geography of educational and social inequalities and the role of peripheral differences in each country. It is very important to mention that according to Eurostat's data of 2019 "the proportion of NEETs is higher in rural regions with $15.0 \%$, compared to urban areas with $12.9 \%$. This difference is greater in Southern and Eastern European countries. The highest rate of risk of poverty or social and educational exclusion in the EU was recorded among people living in rural areas reaching $27.1 \%$, followed by $24.3 \%$ of people living in cities and $22.3 \%$ living in towns and suburbs" (Simões, 2021). The transition from school to the labor market remains undoubtedly a complex long-term process, determined by a variety of personal, family, cultural and socio-economic factors, which drastically affects vulnerable rural NEETs and place them in an extremely precarious and uncertain situation.

\section{Region of Thessaly: Basic Aspects and Dimensions of Economic Profile}

Thessaly is the region used for our examination of the rate of "Rural NEETs". It is located on central-eastern part of the Greek mainland and consists of the prefectures of Larissa, Magnesia / Sporades, Karditsa and Trikala. It is also considered to have an extremely favourable geographical position, as well as many developmental prospects (European Union - European Investment and Structural Funds, 2015). According to the 2011 census, the population of Thessaly is 732,762 people. However, according to the data of the Labour Force Survey of ELSTAT for the second quarter of 2013, its population reaches 725,327 . According to the study of SVKE, Thessaly is distinguished for its high performance in the primary sector of production. It holds the first place in Greece in agricultural sector, while it also presents excellent results in product categories - such as cereals, fruits, vegetables, and legumes. The secondary sector of production is also dynamic in this region, whose participation in the formation of regional GDP exceeds the national average, with local production focusing mainly on metal structures, machinery, food, beverages, wood, and non-metallic minerals. Its participation in the tertiary sector is relatively lagging the national average, based mainly on tourism. In brief, these figures show that the local economy is highly dependent on the primary sector, less on the secondary sector, and even less on the tertiary sector.

Our report recognizes the structural problem of the lack of interconnection among tertiary, primary and secondary sector, while the broader structural problems of the economy are also reflected in the low productivity of labor between the region and the country. In general, according to our research, the activities related to the wider agri-food production and marketing complex and some branches of the processing activity are flourishing in the region. On the contrary, energy sector, tourism, and environment sector lag, showing a wide field for growth and prosperity. The export sector of the region shows an increase of about $6 \%$ per year, with the main export products to be fruits, vegetables, dairy products, cereals and cotton. The opposite picture is presented by the field of research, technological development and innovation, where there is limited activity, concentrated mostly $(85 \%)$ in the two universities in the region, as well as the ICT sector, which has not even formed a specific profile.

\section{Project Description and Essential Clarifications}

The project was addressed to redundant workers of the Supermarket Larissa SA and was co-funded by the European Globalization Adjustment Fund (EGF) and Public Investment Program. The implementation of the project (April 2017-February 2018) was run by the National Institute of Labour and Human Resources in collaboration with eight institutional entities (Notes 1,2). The beneficiary population consisted of 497 persons, all of whom formerly employed by Supermarket Larissa SA, of which 482 were classified as NEETs. Specifically, persons eligible to participate in the project were aged between 15 and 29 years, were unemployed, resided in Thessaly region and had not participated in employment, education or training in the last six months before applying for the project. In addition, specific criteria were taken into account in the selection process by assigning extra points to those with certain social characteristics based on unemployment duration, educational level, income, marital status and whether they belong to disadvantaged groups (i.e. people with disabilities, women victims of domestic violence, formerly imprisoned, minor offenders, former substance users, HIV-seropositive individuals). The final sample of the study was 469 NEETs (Note 3), who took part in a series of actions over a period of 5 months (July to December 2017).

The intervention measures implemented to facilitate their successful reintegration into employment were distributed over the following three axes:

a. professional counselling and support for entrepreneurship development;

b. continuing vocational training programs and specialized training programs;

c. actions to support participants in their relocation to another city in Greece, through the subsidization of mobility and finding a new job. 


\subsection{Data Collection Instruments}

More specifically, a total number of 24 consulting instruments (questionnaires) were used in the whole project (Fotopoulos, Boukouvalas \& Christopoulos, 2020, pp. 113-114), from which the authors have selected 6 for the purpose of the study (see Table 1). It should be noted that these instruments have been developed by professional consultants of the Labour Institute of GSEE and have been used in prior to the current project actions (from 2004 till today) mainly in the form of psychometric questionnaires and have shown an acceptable level of validity and reliability.

Table 1. Consulting instruments used in the study

\begin{tabular}{ll}
\hline Stages & Consulting instruments \\
\hline $\begin{array}{l}\text { Stage A.1: Participants reception/registration and } \\
\text { needs investigation (2 sessions) }\end{array}$ & $\begin{array}{l}\text { Participants' profile (written questionnaire) which } \\
\text { includes their demographic and social characteristics } \\
\text { as well as their prior training and working experience }\end{array}$ \\
Stage A.3.: Personal and professional development & Participants' perceptions of work values (written \\
procedure, initial action plan (6 sessions) & questionnaire with five-point scale Likert type \\
& questions) \\
& $\begin{array}{l}\text { Participants' attitudes towards professional decision } \\
\text { making (written questionnaire with five-point scale }\end{array}$ \\
& Likert type questions) \\
Participants' initial future working preferences \\
Stage A.4: Specialized individual action plan & Participants' individual initial action plan (written \\
development (9 sessions) & questionnaire) \\
Stage A.5: Follow-up procedures (6 sessions) & Employment status monitoring (Follow-up \\
questionnaire by phone interviews)
\end{tabular}

Note. Adapted from Young people Not in Education, Employment or Training in the region of Thessaly, by $\mathrm{N}$. Fotopoulos, K. Boukouvalas \& G. Christopoulos, 2020, pp. 113-114. Copyright 2020 by INE/GSEE.

In short, beneficiaries attended a total of 25 hours individual professional consulting sessions, during which data were collected regarding participants' profile (marital status, educational level, prior participation in training programs, professional experience and prior work status, knowledge of foreign languages and computer skills) as well as their initial requests regarding their future working preferences, their attitudes and perceptions towards professional decision making and work values that are considered important. These sessions aimed at the implementation of specialized interventions based on participants' personal characteristics and their needs, taking also into account the labor market characteristics and needs at that time. To serve this purpose, a detailed individual initial action plan was developed for each of the participants through which the required "steps" were identified for the beneficiaries to be smoothly reintegrated into employment and training. Based on their individual action plan, participants were invited to attend a relevant vocational training program. The training programs' subjects offered to beneficiaries were developed according to a labor market needs assessment of the region of Thessaly that took place in October 2017. During the whole project, precisely 430 participants attended a total of 300 hours of the offered vocational training programs. Furthermore, the beneficiaries took part in basic computer skills certification exams at the end of the program. Finally, two follow-up procedures were scheduled in order to assess the effectiveness of the mentioned implemented measures through monitoring the participants working status over time: the 1st follow-up was conducted 6 months after the completion of the project (June 2018), while the 2nd follow-up approximately 18 months after the completion of the project (August 2019). Both follow-ups were conducted by phone interviews.

\subsection{Data Analysis}

Data from all questionnaires were input into SPSS software, through which a quantitative statistical analysis was performed. We used descriptive statistics (frequency rates, mean values and standard deviations) in order to present our findings. Furthermore, we performed a series of correlations based on the chi-square statistic $(\chi 2)$ so as to examine possible impact of participants' characteristics (gender, age, education, marital status, prior work experience, duration of job seeking etc.) on the formation of their perceptions and attitudes towards all the issues related to our study (employment, training, entrepreneurship, working values, main decisions and perspectives about their future).

\section{Profile of Participants}

The profile of the study population is summarized in Table 2. The project's beneficiaries cover all four prefectures of Thessaly region, while 6 out of 10 NEETs are females. Approximately $42 \%$ of them belong to the upper end of the 
age-range (27-29 years), while the youngest group (16-23 years) accounts for $21 \%$ of the study population. They are mainly graduates of either upper secondary or post-secondary non tertiary vocational education $(52 \%)$ while the proportion of higher education graduates accounts for $27.6 \%$. The vast majority of them $(92.3 \%)$ belong to the very low-income group, earning no more than $4,512 €$ annually (or with a family income up to $9,475 €$ ) without being at the same time members of neither large families nor other disadvantaged groups, apart from being in the state of unemployment.

Table 2. Demographic and Social Characteristics of Participants

\begin{tabular}{|c|c|c|}
\hline Variable & $\mathbf{N}$ & $\%$ \\
\hline \multicolumn{3}{|l|}{ Region } \\
\hline Karditsa & 141 & 30.1 \\
\hline Larissa & 88 & 18.8 \\
\hline Magnesia and Sporades & 139 & 29.6 \\
\hline Trikala & 101 & 21.5 \\
\hline Total & 469 & 100.0 \\
\hline \multicolumn{3}{|l|}{ Gender } \\
\hline Male & 181 & 38.6 \\
\hline Female & 288 & 61.4 \\
\hline Total & 469 & 100.0 \\
\hline \multicolumn{3}{|l|}{ Age group } \\
\hline $16-23$ years & 99 & 21.1 \\
\hline 24-26 years & 174 & 37.1 \\
\hline $27-29$ years & 196 & 41.8 \\
\hline Total & 469 & 100.0 \\
\hline \multicolumn{3}{|l|}{ Higher level of education } \\
\hline Gymnasium - Primary school & 34 & 7.2 \\
\hline General Lyceum & 62 & 13.2 \\
\hline Vocational Lyceum (EPAL) - Vocational School (EPAS) & 188 & 40.1 \\
\hline Institute of Vocational Training & 56 & 11.9 \\
\hline Technological Educational Institutes & 50 & 10.7 \\
\hline Higher Educational Institutes & 72 & 15.4 \\
\hline Postgraduate studies & 7 & 1.5 \\
\hline Total & 469 & 100.0 \\
\hline \multicolumn{3}{|l|}{ Marital status } \\
\hline Single & 344 & 73.5 \\
\hline Married & 104 & 22.2 \\
\hline In cohabiting partnership - Divorced & 20 & 4.3 \\
\hline Total & 468 & 100.0 \\
\hline \multicolumn{3}{|l|}{ Family size } \\
\hline Large family ( $>3$ children) & 54 & 11.5 \\
\hline Family of 3 children & 106 & 22.6 \\
\hline None of the above & 309 & 65.9 \\
\hline Total & 469 & 100.0 \\
\hline \multicolumn{3}{|l|}{ Disadvantaged groups } \\
\hline Yes & 37 & 7.9 \\
\hline No & 432 & 92.1 \\
\hline Total & 469 & 100.0 \\
\hline \multicolumn{3}{|l|}{ Income group } \\
\hline Individual Income $0-4,512 €$ & 366 & 78.0 \\
\hline Individual Income 4,513-9,000€ & 9 & 1.9 \\
\hline Individual Income 9,001-12,000 € & 1 & 0.2 \\
\hline Family Income $0-9,475 €$ & 67 & 14.3 \\
\hline Family Income $9,476-12,000 €$ & 8 & 1.7 \\
\hline Family Income $12,001-16,001 €$ & 10 & 2.1 \\
\hline Family Income $16,001-26,000 €$ & 8 & 1.7 \\
\hline Total & 469 & 100.0 \\
\hline
\end{tabular}

Note. Adapted from Young people Not in Education, Employment or Training in the region of Thessaly, by $\mathrm{N}$. Fotopoulos, K. Boukouvalas \& G. Christopoulos, 2020, pp. 213-215. Copyright 2020 by INE/GSEE.

Both language and computer skills are undoubtedly considered structural parameters in the context of horizontal skills required to find a job in the labor market. In the NEETs study population, almost half of them state lack of foreign language and/or computer skills certification, despite the higher rates of self-reported knowledge (see Table 3). Regarding their prior training experience, 2 out of 3 NEETs have attended vocational or training programs in the past, a fact that is indicative of their continuous attempt to obtain marginal survival benefit through the process of training/retraining. In the absence of other alternatives, they maintain their hope of entering the labour market through 
training programs. Moreover, most of them are characterized as long-term unemployed since 7 out 10 participants have been seeking for a job for 1 year to more than 3 years in total.

Table 3. Participants' Prior Training and Working Experience

\begin{tabular}{|c|c|c|}
\hline Variable & $\mathbf{N}$ & $\%$ \\
\hline \multicolumn{3}{|c|}{ Foreign language knowledge } \\
\hline Yes & 302 & 64.4 \\
\hline No & 167 & 35.6 \\
\hline Total & 469 & 100.0 \\
\hline \multicolumn{3}{|c|}{ Foreign language certificate } \\
\hline Yes & 206 & 68.2 \\
\hline No & 96 & 31.8 \\
\hline Total & 302 & 100.0 \\
\hline \multicolumn{3}{|c|}{ Computer skills knowledge } \\
\hline Yes & 369 & 78.7 \\
\hline No & 100 & 21.3 \\
\hline Total & 469 & 100.0 \\
\hline \multicolumn{3}{|c|}{ Computer skills certificate } \\
\hline Yes & 268 & 72.6 \\
\hline No & 101 & 27.4 \\
\hline Total & 369 & 100.0 \\
\hline \multicolumn{3}{|c|}{ Prior attendance of training or vocational programs } \\
\hline Yes & 301 & 64.2 \\
\hline No & 168 & 35.8 \\
\hline Total & 469 & 100.0 \\
\hline \multicolumn{3}{|c|}{ Duration of job seeking } \\
\hline 0-6 months & 56 & 12.1 \\
\hline 7-12 months & 81 & 17.5 \\
\hline $1-3$ years & 148 & 31.9 \\
\hline$>3$ years & 179 & 38.6 \\
\hline Total & 464 & 100.0 \\
\hline
\end{tabular}

Note. Adapted from Young people Not in Education, Employment or Training in the region of Thessaly, by N. Fotopoulos, K. Boukouvalas \& G. Christopoulos, 2020, pp. 216-217. Copyright 2020 by INE/GSEE.

According to their initial statements at the time of registration, NEETs' future working preferences are mainly leaning towards full-time paid employment, especially in morning shift jobs (see Table 4). The increased rate (37.9\%), however, of the participants who appear willing to work in any shift is indicative of their urgent desire to find a job as soon as possible. 
Table 4. Participants' Initial Future Working Preferences

\begin{tabular}{lrr}
\hline Variable & N & \% \\
\hline Desire to be self-employed & 102 & 21.8 \\
Yes & 367 & 78.2 \\
No & 469 & 100.0 \\
Total & & \\
Desire to work for an employer & 436 & 92.9 \\
Yes & 33 & 7.1 \\
No & 469 & 100.0 \\
Total & & \\
Desired type of employment & 399 & 86.0 \\
Full-time & 30 & 6.5 \\
Part-time & 35 & 7.5 \\
No preference/no declaration & 464 & 100.0 \\
Total & & \\
Desired working hours & 262 & 56.7 \\
Morning shift & 6 & 1.3 \\
Afternoon/Evening shift & 4 & 0.9 \\
Night shift & 15 & 3.2 \\
Split shift & 175 & 37.9 \\
No preference & 462 & 100.0 \\
Total & & \\
\hline
\end{tabular}

Note. Adapted from Young people Not in Education, Employment or Training in the region of Thessaly, by N. Fotopoulos, K. Boukouvalas \& G. Christopoulos, 2020, pp. 217-218. Copyright 2020 by INE/GSEE.

Two measuring instruments were used in the project in order to capture participants' attitudes and perceptions towards professional decision making and work values that they considered important, based on 30 and 21 five-point scale Likert scale questions/statements respectively. For the sake of brevity, not all questions/statements are presented here but only the most significant ones that we believe shed some light on the subject. According to Table 5, the fear of unemployment seems to play an important role in the lives of young people, as it produces the generalized feeling of intense anxiety. Most of the participants appear to insist on permanent and full-time employment as guarantee of a calm and "normal" life. The issue of wages is also evaluated positively, since it is widely accepted that a good salary is strongly connected with the assurance of quality of life. In addition, social contribution through their work is highlighted as very important. It is noteworthy that most of them do not seem to adopt the stereotype of depreciation of manual labor, as they do not consider office jobs as particularly important. Nevertheless, permanent, full-time paid employment is the dominant preference over other forms of employment, such as self-employment or the development of social or cooperative entrepreneurship. 
Table 5. Participants' Perceptions of Work Values

\begin{tabular}{|c|c|c|c|c|c|c|}
\hline \multirow[b]{2}{*}{ Questions/statements } & \multicolumn{5}{|c|}{ Frequency rates $(\%)$} & \multirow[b]{2}{*}{ Mean } \\
\hline & $\begin{array}{l}\text { Completely } \\
\text { insignificant } \\
\text { to me } \\
\text { (1) }\end{array}$ & $\begin{array}{c}\text { Of little } \\
\text { importance } \\
\text { (2) }\end{array}$ & $\begin{array}{c}\text { Quite } \\
\text { important } \\
\text { (3) }\end{array}$ & $\begin{array}{c}\text { Very } \\
\text { important to } \\
\text { me } \\
\text { (4) }\end{array}$ & Total & \\
\hline $\begin{array}{l}\text { To have a secure job } \\
\text { without fear of } \\
\text { unemployment }\end{array}$ & 0.2 & 3.4 & 25.9 & 70.5 & 100.0 & 3.67 \\
\hline To have a good wage & 1.1 & 3.9 & 43.8 & 51.3 & 100.0 & 3.45 \\
\hline $\begin{array}{l}\text { To satisfy my tendency to } \\
\text { serve those in need }\end{array}$ & 1.7 & 8.6 & 42.2 & 47.4 & 100.0 & 3.35 \\
\hline $\begin{array}{l}\text { Not to interfere with my } \\
\text { personal life }\end{array}$ & 3.2 & 10.1 & 38.1 & 48.5 & 100.0 & 3.32 \\
\hline To have an office job & 37.1 & 45.3 & 13.6 & 4.1 & 100.0 & 1.85 \\
\hline
\end{tabular}

Notes. Adapted from Young people Not in Education, Employment or Training in the region of Thessaly, by N. Fotopoulos, K. Boukouvalas \& G. Christopoulos, 2020, pp. 219-220. Copyright 2020 by INE/GSEE.

Statements/questions are ranked by the mean values. The mean value is calculated as an average from the scores assigned to each category of the Likert scale. Possible values range between 1 and 4, with higher values corresponding to very important factors and lower values to less important ones.

$\mathrm{N}=464$.

One important factor in the decision-making process is the role of the educational level of participants. With no doubt NEETs who appear with higher educational attainment, shape a better-structured approach of their future strategy. They gather information, exchange views or evidence-based practices, following a more rational process for their personal decisions. In order to assess the impact of the educational level of participants on their attitudes towards professional decision making, we use the chi-square test (see Table 6). More precisely, 3 out of 4 (74.6\%) participants report they rarely make decisions without first gathering all the necessary information. This statement appears to be correlated with the educational level of participants, $\mathrm{X}^{2}(4, \mathrm{~N}=461)=18.002, \mathrm{p}=.001$, since the positive response rate of higher education graduates is significantly higher $(85.2 \%)$ as opposed to primary education graduates (73.5\%) and upper secondary vocational education graduates $(64.8 \%)$. It is noteworthy that even though the term "intuition" is vague and indefinite, it is recognized as an important factor in decision-making, with more than half of participants (54.4\%) stating that they make decisions based on their feelings and intuition. The positive response rate to this statement varies significantly across the different educational levels of participants, $\mathrm{X}^{2}(4, \mathrm{~N}=461)=28.579, \mathrm{p}=.000$. More precisely, primary education graduates and upper secondary vocational education graduates $(61.8 \%$ and $67.6 \%$ respectively) appear to trust their intuition significantly more than higher education graduates $(39.1 \%)$. In general, we can conclude that the higher the educational level, the more methodical, organized and rationalized the participants appear to be when it comes to professional decision making. Furthermore, $37.7 \%$ of the participants claim that it is very hard for them to make important decisions without any help. The effect of educational level is prevalent here too, since primary education graduates have a significantly higher tendency to seek for others' help in order to make decisions $(67.6 \%)$ in comparison to the other levels, $\mathrm{X}^{2}(4, \mathrm{~N}=461)=20.498, \mathrm{p}=.000$. 
Table 6. Participants’ Attitudes Towards Professional Decision Making by Educational Level (Frequency Rates \%)

\begin{tabular}{|c|c|c|c|c|c|c|c|}
\hline $\begin{array}{l}\text { Questions/ } \\
\text { statements }\end{array}$ & $\begin{array}{l}\text { Primary } \\
\text { education } \\
(\mathrm{N}=34)\end{array}$ & $\begin{array}{l}\text { General } \\
\text { Lyceum } \\
(\mathrm{N}=62)\end{array}$ & $\begin{array}{l}\text { Vocational } \\
\text { Lyceum } \\
\text { (EPAL) - } \\
\text { Vocational } \\
\text { School } \\
\text { (EPAS) }\end{array}$ & $\begin{array}{c}\text { Institute of } \\
\text { Vocational } \\
\text { Training } \\
(\mathrm{N}=55)\end{array}$ & $\begin{array}{l}\text { Higher } \\
\text { education } \\
(\mathrm{N}=128)\end{array}$ & $\begin{array}{c}\text { Total } \\
(\mathrm{N}=461)\end{array}$ & $\begin{array}{l}\text { Chi square } \\
\text { tests of } \\
\text { independence }\end{array}$ \\
\hline & & & $(\mathrm{N}=182)$ & & & & \\
\hline
\end{tabular}

\section{It is really difficult for me to make important decisions without any help}

$\begin{array}{lrrrrrrr}\text { No } & 32.4 & 79.0 & 62.6 & 60.0 & 62.5 & 62.3 & \chi^{2}(4)= \\ \text { Yes } & 67.6 & 21.0 & 37.4 & 40.0 & 37.5 & 37.7 & \begin{array}{c}20.498 \\ \mathrm{p}=.000\end{array} \\ \text { Total } & 100.0 & 100.0 & 100.0 & 100.0 & 100.0 & 100.0 & \mathrm{n}=461\end{array}$

When I make a decision, I just trust my feelings and my intuition

$\begin{array}{lrrrrrrr}\text { No } & 38.2 & 56.5 & 32.4 & 45.5 & 60.9 & 45.6 & \chi^{2}(4)= \\ \text { Yes } & 61.8 & 43.5 & 67.6 & 54.5 & 39.1 & 54.4 & 28.579 \\ & 100.0 & 100.0 & 100.0 & 100.0 & 100.0 & 100.0 & \mathrm{p}=.000 \\ \text { Total } & & & & & & & \end{array}$

I rarely make an important decision without first gathering all the necessary information

\begin{tabular}{lrrrrrrr} 
No & 26.5 & 19.4 & 35.2 & 23.6 & 14.8 & 25.4 & $\chi^{2}(4)=$ \\
Yes & 73.5 & 80.6 & 64.8 & 76.4 & 85.2 & 74.6 & $\begin{array}{c}18.002 \\
\text { Total }\end{array}$ \\
\hline
\end{tabular}

Note. Adapted from Young people Not in Education, Employment or Training in the region of Thessaly, by $\mathrm{N}$. Fotopoulos, K. Boukouvalas \& G. Christopoulos, 2020, pp. 165-167. Copyright 2020 by INE/GSEE.

According to the initial action plans developed for each of the participants (see Table 7), only $2.8 \%$ of them seem to follow the perspective of a social - collaborative entrepreneurship, while higher is the percentage of those who are pursuing to establish their own firm (12\%). As already mentioned, the vast majority of participants (93.2\%) are in search of a paid job, which combined with the other dimensions of their profile highlighted in the present paper, demonstrates how prevalent the criteria of a stable, morning and full-time job are in the seeking process, and how self-employment and social - collaborative entrepreneurship is of little interest to them.

Table 7. Participants' Individual Initial Action Plan (Frequency Rates \%)

\begin{tabular}{lrr}
\hline Variable & N & \% \\
\hline Job search and find & 437 & \\
$\quad$ Yes & 32 & 93.2 \\
No & 469 & 6.8 \\
Total & & 100.0 \\
Development of social - collaborative entrepreneurship & 13 & 2.8 \\
Yes & 456 & 97.2 \\
No & 469 & 100.0 \\
Total & & 12.0 \\
Development of individual entrepreneurship & 56 & 88.0 \\
Yes & 413 & 100.0 \\
No & 469 & \\
Total & & \\
\hline
\end{tabular}

Note. Adapted from Young people Not in Education, Employment or Training in the region of Thessaly, by $\mathrm{N}$. Fotopoulos, K. Boukouvalas \& G. Christopoulos, 2020, p. 223. Copyright 2020 by INE/GSEE. 
In order to avoid possible confusion, it should be clarified at this point that the observed differences in values between Tables 4 and 7 are due to the different measuring instruments from which the data were derived. More precisely, values of Table 4 are based on the initial future working preferences of participants, a questionnaire that was filled at the time of registration in the project, while values of Table 7 are based on the individual initial action plan which was developed later on the project in collaboration with the professional consultants. At that time, some intervention measures (i.e. individual sessions) had already taken place and, thus, some minor changes in the distribution rates were expected, since it is possible that some of the participants had changed their minds in some issues, such as their desire for self-employment.

\section{Follow-up Results}

Six months after the completion of the project (June 2018), 8 out 10 NEETs of the study population remained unemployed (79.6\%) (see Table 8). It is worth mentioning that $15.3 \%$ of the unemployed ones had abandoned their search for a job. From the total amount of the participants in the sample who were employed at that time (20.4\%), $88.5 \%$ were on a paid job, while the remaining $11.5 \%$ declared self-employed. From those who declared employed, $60 \%$ were working full time, $25.9 \%$ part time while the remaining $14.1 \%$ did not provide any answer. Additionally, $41.2 \%$ of those on a paid job were on a fixed-term employment contract and $43.5 \%$ on an open-ended contract, while $15.3 \%$ did not provide any answer.

Approximately eighteen months after the completion of the project (2nd follow-up in August 2019), the unemployment rate of the study population had only slightly fallen to $75.9 \%$, which in absolute numbers translates to an increase of 17 persons having managed to transit from unemployment to employment (see Table 8 ). At that time, only $0.6 \%$ ( 2 persons) of the unemployed ones appeared not seeking a job. This rate had been decreased by $96.1 \%$. The ratio of self-employed had increased by 3.5 percentage points to $15 \%$ at that time. There was also an increase of 8.8 percentage points in the ratio of full-time employees to $68.8 \%$ and of 10.8 percentage points in the ratio of those on a fixed-term employment contract which was formed to $52 \%$.

Table 8. Participants' Employment Status Based on the Two Follow-ups $(2018,2019)$

\begin{tabular}{|c|c|c|c|c|c|c|}
\hline \multirow[b]{2}{*}{ Variable } & \multicolumn{2}{|c|}{$\begin{array}{l}\text { 1st follow-up } \\
\text { (June 2018) }\end{array}$} & \multicolumn{2}{|c|}{$\begin{array}{l}\text { 2nd follow-up } \\
\text { (August 2019) }\end{array}$} & \multicolumn{2}{|c|}{$\begin{array}{l}\text { Absolute } \\
\text { Change }\end{array}$} \\
\hline & $\mathrm{N}$ & $\%$ & $\mathrm{~N}$ & $\%$ & $\mathrm{~N}$ & $\%$ \\
\hline \multicolumn{7}{|l|}{ Working status } \\
\hline Unemployed & 373 & 79.6 & 356 & 75.9 & -17 & -3.7 \\
\hline Actively seeking a job & 316 & 67.4 & 354 & 75.5 & 38 & 8.1 \\
\hline Not seeking a job & 57 & 12.2 & 2 & 0.4 & -55 & -11.8 \\
\hline Employed & 96 & 20.4 & 113 & 24.1 & 17 & 3.7 \\
\hline In paid job & 85 & 18.1 & 96 & 20.5 & 11 & 2.4 \\
\hline Self-employed & 11 & 2.3 & 17 & 3.6 & 6 & 1.3 \\
\hline Total & 469 & 100 & 469 & 100 & - & - \\
\hline \multicolumn{7}{|l|}{ Type of employment } \\
\hline Full-time & 51 & 60 & 66 & 68.8 & 15 & 8.8 \\
\hline Part-time & 22 & 25.9 & 30 & 31.2 & 8 & 5.3 \\
\hline NA & 12 & 14.1 & & & -12 & -14.1 \\
\hline Total & 85 & 100 & 96 & 100 & 11 & - \\
\hline \multicolumn{7}{|c|}{ Type of employment contract } \\
\hline Open-ended contract & 37 & 43.5 & 42 & 43.8 & 5 & 0.3 \\
\hline Fix-termed contract & 35 & 41.2 & 50 & 52 & 15 & 10.8 \\
\hline NA & 13 & 15.3 & 4 & 4.2 & -9 & -11.1 \\
\hline Total & 85 & 100 & 96 & 100 & 11 & - \\
\hline
\end{tabular}

Note. Adapted from Young people Not in Education, Employment or Training in the region of Thessaly, by N. Fotopoulos, K. Boukouvalas \& G. Christopoulos, 2020, p. 226. Copyright 2020 by INE/GSEE. 
While Table 8 reports the total changes for each of the working status categories, it should be noted that when monitoring the study population within each category significant changes took place between the two follow-up time points. According to Table 9, at the time of the 2nd follow-up 83.2\% (263 participants) of the total 316 persons who were unemployed and actively looking for a job at the time of the 1st follow up, remained unemployed, while $15.2 \%$ (48 participants) had managed to find a job and $0.9 \%(\mathrm{n}=2)$ declared self-employed. It is worth noting that 2 persons $(0.6 \%)$ had given up looking for a job at that time. Out of the total number of 57 participants who were still in the state of unemployment at the time of the 1st follow-up but were not seeking for a job, the $80.7 \%$ of them remained unemployed in August 2019 but had started again to actively look for a job, while the rest of them (11 participants) had managed to find a job. Regarding those who were on a paid job at the time of the 1st follow-up (85 participants), almost half of them $(50.6 \%)$ had lost their job and had returned again to the unemployment state by the time of the 2 nd follow-up, 5.6\% declared self-employed and the rest 43.5\% (37 participants) reported themselves as still employees. Finally, the $81.8 \%$ (9 participants) who were self-reported as self-employed in June 2018, appear to remain in the same employment category, while the rest 2 participants $(18.2 \%)$ had moved to unemployment by the time of the 2 nd follow up.

Table 9. Employment Status Monitoring per Category Based on the Two Follow-ups (2018, 2019)

\begin{tabular}{|c|c|c|c|c|c|c|}
\hline & & \multicolumn{5}{|c|}{ 2nd follow-up (August 2019) } \\
\hline & & $\begin{array}{c}\text { Unemployed: } \\
\text { Actively } \\
\text { seeking a job }\end{array}$ & $\begin{array}{c}\text { Unemployed: } \\
\text { Not seeking a } \\
\text { job }\end{array}$ & $\begin{array}{l}\text { Employed: } \\
\text { Employee/ } \\
\text { Worker }\end{array}$ & $\begin{array}{l}\text { Employed: } \\
\text { Self-employed }\end{array}$ & Total \\
\hline \multirow{5}{*}{ 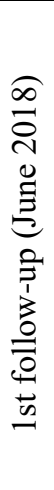 } & $\begin{array}{l}\text { Unemployed: } \\
\text { Actively seeking a } \\
\text { job }\end{array}$ & 263 & 2 & 48 & 3 & 316 \\
\hline & $\begin{array}{l}\text { Unemployed: Not } \\
\text { seeking a job }\end{array}$ & 46 & 0 & 11 & 0 & 57 \\
\hline & $\begin{array}{l}\text { Employed: } \\
\text { Employee/Worker }\end{array}$ & 43 & 0 & 37 & 5 & 85 \\
\hline & $\begin{array}{l}\text { Employed: } \\
\text { Self-employed }\end{array}$ & 2 & 0 & 0 & 9 & 11 \\
\hline & Total & 354 & 2 & 96 & 17 & 469 \\
\hline
\end{tabular}

Note. Adapted from Young people Not in Education, Employment or Training in the region of Thessaly, by N. Fotopoulos, K. Boukouvalas \& G. Christopoulos, 2020, p. 190. Copyright 2020 by INE/GSEE.

\section{Conclusion - Discussion}

Our report emphasizes on the current problem of NEETs in Thessaly's region theorizing it as structural issue which is based on the Greek pathogeny. According to our findings, even though the region of Thessaly has significant potentials for growth and economic prosperity, it occurs with a serious number of structural weaknesses which shape an extremely problematic socio-economic environment, especially for those who are aged 15-34 years old. The NEET's issue remains with no doubt a very complex equation which is still unsolved not only for Greece but for the most European countries.

Through the quantitative analysis of data our findings shape a rational proposal by highlighting the request for a solid transition from the "specialized individual action plans" to the "structured social interventions" (Simões, \& do Rio, 2020). Additionally, during this process the mode of the individual internalization and the subjective way of reaction to the necessity of the external reality seems to have a crucial role. That's why one of the most significant and challenging part of our research is the effort to spot the personal routes and perceptions (Beck, 2015) through the stressful conditions of educational and social exclusion.

Beyond any doubt, NEET's issue is linked with diachronic pathogenies which have developed vertically from "bottom to top". This means that in order to establish a new strategy against unemployment, poverty and social exclusion, we have to take into consideration the whole structure of the Greek educational system as well as the transitional pathways from education and training to the field of employment. Additionally, we need to focus on the special conditions at local and regional level decoding the concrete peculiarities towards a solid and well-structured perspective by alleviating the more socially vulnerable groups of youth. 


\section{Notes}

Note 1. The Institute of Labour of the General Confederation of Greek Labour (INE GSEE), the Institute of Commerce and Services (IN.EM.Y) of the Hellenic Confederation of Commerce and Entrepreneurship (ESEE) of the Hellenic Trade and Entrepreneurship Development Center, the Institute of Small Enterprises of the Hellenic Confederation of Professionals, Craftsmen \& Merchants) (IME GSEVEE), the Karditsa Development Company (A.K.) of the University of Thessaly-ELKE, the Center of Vocational Training of INE/GSEE and the Center of Vocational training of GSEVEE.

Note 2. The data are presented by the EIEAD, Vocational training of Young People not Employment, Education or training (NEETs) in the framework of the European Globalization Adjustment Fund: The case of the program for the Larissa Supermarket SA ", edited by Paidoussi, X, Athens, EIEAD, 2019, pp. 36-38.

Note 3. After excluding 13 beneficiaries that were living outside the region of Thessaly.

\section{References}

Beck, V. (2015). Learning providers' work with NEET young people. Journal of Vocational Education \& Training, 67(4), 482-496. https://doi.org/10.1080/13636820.2015.1086412

EIEAD. (2019). Vocational training of young people out of employment, education or training (NEETs) in the framework of the European Globalization Adjustment Fund: The case of the program for the Larissa Supermarket $S A$, (ed. Paidoussi, H). Athens: EIEAD. (in Greek)

Elder, S. (2015). What does NEETs mean and why is the concept so easily misinterpreted?. Work 4 Youth Technical Brief, Geneva: ILO Publishing. https:/www.ilo.org/wcmsp5/groups/public/---dgreports/---dcomm/documents/publication/wcms 343153.pdf

Eurofound. (2012). Young people and NEETs in Europe: First findings. Dublin. https://doi.org/10.2806/3177

Eurofound. (2014). Mapping youth transitions in Europe. Luxembourg: Publications Office of the European Union. https://doi.org/10.2806/51024

Eurofound. (2016). Exploring the diversity of NEETs. Luxembourg: Publications Office of the European Union. https://doi.org/10.2806/62307

European Union - European Investment and Structural Funds. (2015). The Thessaly Regional Operational Program 2014-2020. Annex I: Main Development Characteristics of the Thessaly Region. (in Greek)

Eurostat. (2019). Statistics on young people neither in employment nor in education or training. Retrieved April 15, 2020, from

https:/ec.europa.eu/eurostat/statistics-explained/index.php?title=Statistics_on_young_people_neither_in_employm ent_nor_in_education_or_training\#Young_people_neither_in_employment_nor_in_education_or_training

Fotopoulos, N. (2013). The problem of NEETs and the Greek reality. Seeking solutions to Greece's Memorandum. Absents' Barometer: The NEETs (Young People Not in Education, Employment or Training) in Greece, Athens: Sideris, 241-263. (in Greek)

Fotopoulos, N., Boukouvalas, K., \& Christopoulos, G. (2020). Young people Not in Education, Employment or Training in the region of Thessaly: from specialized individual action plans to structured social interventions. Athens: Labour Institute of GSEE. (in Greek)

Huang, X. (2019). Understanding Bourdieu - Cultural Capital and Habitus. Review of European Studies, 11, 45. https://doi.org/10.5539/res.v11n3p45

Jenks, C. (1993). The analytic basis of cultural reproduction theory. In C. Jenks (Ed.). Cultural reproduction (pp.1-17). London: Routledge.

Kyridis, A., \& Fotopoulos, N. (2016). 'Dimensions of Social Vulnerability and Intervention for the Social Edition of the Neets', in N. Papadakis, A. Kyridis, N. Fotopoulos (ed.) New Generation and NEETs in Greece during the crisis The urgent dimensions of the problem: Research and comprehensive intervention, Athens: Sideris, 161-180.

Maguire, S. (2015). NEET, unemployed, inactive or unknown-why does it matter?. Educational research, 57(2), 121-132. https://doi.org/10.1080/00131881.2015.1030850

Mascherini, M. (2019). Origins and future of the concept of NEETs in the European policy agenda. In Youth Labor in Transition (pp. 503-529). Oxford University Press. https://doi.org/10.1093/oso/9780190864798.003.0017

Papadakis, N., Kyridis, A., \& Fotopoulos, N. (eds.). (2016). New Generation and NEETs in Greece during the crisis The urgent dimensions of the problem: Research and comprehensive intervention. Athens: Sideris. (in Greek) 
Papadakis, N., Kyridis, A., \& Papargyris, A. (2015). Searching for absents: The State of things for the NEETs (young people Not in Education, Employment or Training) in Greece. An overview. Journal of Sociological Research, 6(1), 44-75. https://doi.org/10.5296/jsr.v6i1.7228

Simões, F. (2021, January 21). Tackling Youth Rural NEETs social and economic exclusion. COST. https://www.cost.eu/rural-neets/

Simões, F., \& do Rio, N. B. (2020). How to increase rural NEETs professional involvement in agriculture? The roles of youth representations and vocational training packages improvement. Journal of Rural Studies, 75, 9-19. https://doi.org/10.1016/j.jrurstud.2020.02.007

Yates, S., \& Payne, M. (2006). Not so NEET? A critique of the use of 'NEET' in setting targets for interventions with young people. Journal of youth studies, 9(3), 329-344. https://doi.org/10.1080/13676260600805671

\section{Copyrights}

Copyright for this article is retained by the author(s), with first publication rights granted to the journal.

This is an open-access article distributed under the terms and conditions of the Creative Commons Attribution license which permits unrestricted use, distribution, and reproduction in any medium, provided the original work is properly cited. 